\title{
INDEKS KESESUAIAN GARAM (IKG) UNTUK MENENTUKAN KESESUAIAN LOKASI PRODUKSI GARAM; ANALISIS LOKASI PRODUKSI GARAM DI KABUPATEN TUBAN DAN KABUPATEN PROBOLINGGO
}

\author{
Andi Kurniawana, $^{\text {a,b,c, }}$, Abdul Aziz Jaziri ${ }^{\text {a,b,c, }}$, Abdul Aziz Amin ${ }^{\text {b,c }}$, Lutfi Ni’matus Salamah ${ }^{\text {b,c }}$ \\ ${ }^{a}$ Fakultas Perikanan dan Ilmu Kelautan, Universitas Brawijaya, Malang, Jawa Timur - Indonesia \\ ${ }^{b}$ Pusat Studi Pesisir dan Kelautan, Universitas Brawijaya, Malang, jawa Timur - Indonesia \\ ${ }^{c}$ Institute for Sustainable Fisheries and Aquatic Ecosystem, Malang, Jawa Timur - Indonesia
}

*Koresponden penulis: andi_k@ub.ac.id

\begin{abstract}
Abstrak
Garam merupakan komoditas penting yang banyak digunakan secara luas dari kepentingan konsumsi sampai dengan industri. Salah satu faktor utama yang menentukan keberhasilan produksi garam ini adalah kesesuaian lokasi produksi garam. Hanya saja, belum ada metode yang dapat digunakan sebagai acuan dalam penentuan tingkat kesesuaian lokasi produksi garam. Penelitian ini bertujuan untuk menyusun Indeks Kesesuaian Garam (IKG) untuk menganalsis kesesuaian lokasi produksi garam. Dalam penelitian ini, IKG digunakan untuk menganalisis lokasi produksi garam di Kabupaten Tuban dan Kabupaten Probolinggo, Jawa Timur. IKG disusun berdasarkan sembilan parameter kesesuaian yang terdiri dari curah hujan, permeabilitas tanah, jenis tanah, lama penyinaran, kelembapan udara, kecepatan angin, suhu udara, tingkat penguapan dan tingkat kejenuhan air bahan baku. Hasil penelitian ini menunjukkan bahwa nilai IKG lokasi produksi garam di Kabupaten Tuban (Desa Leranwetan) adalah sebesar 86,84\% yang mengindikasikan kalau lokasi ini sudah sangat sesuai untuk produksi garam. Nilai IKG lokasi produksi garam di Kabupaten Probolinggo (Desa Kalibuntu) adalah sebesar $81,57 \%$ yang mengindikasikan lokasi ini cukup sesuai sebagai lokasi produksi garam. Studi ini melaporkan untuk pertama kali metode yang dapat digunakan untuk menganalisis tingkat kesesuaian lokasi untuk produksi garam.
\end{abstract}

Kata Kunci: garam, garam laut, indeks kesesuaian garam, lokasi produksi

\begin{abstract}
Salt is a valuable commodity that is widely used from consumption to industrial purposes. One of the main factors that determine the success of this salt production is the suitability of the location of salt production. However, no method that can be used as a reference in assessing the suitability of salt production locations. This study aims to develop the Salt Suitability Index (IKG) that can be used to analyze the suitability level of the salt production sites. In this study, IKG was used to analyze salt production locations in Tuban and Probolinggo Regency, East Java. IKG is compiled based on nine parameters of suitability that consist of rainfall, soil permeability, soil type, irradiation time, air humidity, wind speed, air temperature, evaporation rate and length of salt production. The results of this study indicate that the IKG value of salt production sites in Tuban Regency (Leranwetan Village) is $86.84 \%$, which suggests that this location is very suitable for salt production. The IKG value of a salt production location sites in Probolinggo Regency (Kalibuntu Village) is $81.57 \%$, which indicates that this location is quite suitable as a salt production location. This study report for the first time the method that can be applied to analyze the suitability level of the salt production site.
\end{abstract}

Keywords: sea salt, salt, salt production site, salt suitability index

\section{PENDAHULUAN}

Garam merupakan komoditas penting yang banyak digunakan secara luas dari kepentingan konsumsi sampai dengan industri. Garam didefinisikan sebagai benda padat berwarna putih berbentuk kristal yang merupakan kumpulan senyawa dengan bagian terbesar $\mathrm{NaCl}(>80 \%)$ serta senyawa lainnya, seperti magnesium klorida, magnesium sulfat, dan kalsium klorida [1]. Sumber garam yang didapat di alam dapat berasal dari air laut, air danau asin, deposit dalam tanah, tambang garam, sumber air dalam tanah ataupun sungai 
berair payau [2]. Di Indonesia, garam diproduksi dengan memanfaatkan bahan baku air laut ataupun air payau.

Indonesia merupakan negara yang memiliki pantai terpanjang ke empat di dunia yaitu $95,181 \mathrm{~km}$ dan memiliki potensi air laut sebagai bahan dasar pembuatan garam [3]. Namun, produksi garam nasional hanya mampu memenuhi garam konsumsi dan tidak bisa memenuhi garam industri [4], hal ini terutama disebabkan oleh: 1) teknologi produksi dan 2) lokasi/lahan produksi yang tidak tepat. Teknologi produksi garam di Indonesia secara umum masih tradisional dan sangat bergantung pada musim kemarau. Tahun 2016, produksi garam di Indonesia hanya mencapai $4,6 \%$ dari target produksi nasional sebanyak 3,9 jta ton. Kegagalan pencapaian target tersebut terutama dikarenakan akibat aktivitas La-nina yang berdampak kemarau basah sepanjang tahun 2016. Permasalahan utama lain yang dihadapi dalam produksi garam di Indonesia adalah kualitas garam $(\mathrm{NaCl})$ yang dihasilkan belum memenuhi Standar Nasional Indonesia (SNI) [5], [6].

Lokasi produksi garam di Indonesia umumnya berdekatan dengan sumber air bahan baku garam, baik langsung dari laut maupun dari aliran sungai atau muara sungai berair payau. Karakteristik lokasi produksi garam di Indonesia sebagian besar sama, dimana kepemilikan lahan produksi antar petambak garam satu dengan yang lainnya saling berdekatan dan melakukan proses produksi yang juga relatif sama. Secara umum proses produksi dimulai dari kolam penampungan air (bozem), peminihan, dan meja kristalisasi [7].

Untuk meningkatkan efektifitas dan efisiensi produksi garam di Indonesia, pemerintah melalui Kementrian Kelautan dan Perikanan (KKP) mencanangkan program integrasi lahan produksi garam dalam satu kawasan sebesar 15 ha. Salah satu tujuan utama dari program ini adalah untuk meningkatkan produktivitas produksi garam menjadi 80-100 ton/ha per periode panen. Salah satu faktor terpenting dalam pelaksanaan kebijakan ini adalah ketepatan dalam menentukan lokasi produksi garam.
Jawa Timur merupakan lumbung garam terbesar di Indonesia. Kabupaten Tuban dan Kabupaten Probolinggo merupakan daerah pesisir yang berkontribusi pada pencapaian target produksi garam di Jawa Timur. Secara umum, lokasi produksi garam di kedua kabupaten tersebut berbeda, dimana lokasi produksi garam di Kabupaten Tuban sebagian besar berada jauh dari laut dengan sumber air utamanya berasal dari aliran sungai berair payau, sedangkan lokasi produksi garam di Kabupaten Probolinggo berada di tepi pantai dengan sumber air utama berasal dari laut. Perbedaan kedua lokasi produksi tersebut sangat dipengaruhi oleh faktor-faktor pendukung produksi garam, seperti curah hujan, kecepatan angin, kelembaban udara, lama penyinaran, jenis tanah, dan derajat kejenuhan air bahan baku produksi garam (Baume/Be) [8].

Untuk mendukung usaha peningkatan produksi garam khususnya program integrasi lahan produksi garam, dibutuhkan analisis mengenai kesesuaian lokasi produksi garam di masing-masing daerah, termasuk di Kabupaten Tuban dan Kabupaten Probolinggo. Hanya saja, dalam batas pengetahuan penulis, saat ini belum tersedianya metode atau acuan untuk menentukan tingkat kesesuaian suatu lokasi untuk dijadikan sentra produksi garam. Tujuan dari penelitian ini adalah mengembangkan metode analisis untuk menjawab permasalahan diatas. Dalam penelitian ini, penilaian kesesuaian suatu lokasi untuk menjadi lokasi produksi garam dikembangkan dalam bentuk Indeks Kesuaian Garam (IKG).

Penyusunan IKG didasarkan pada sembilan parameter yang menentukan proses produksi garam, yaitu curah hujan, permeabilitas tanah, jenis tanah, lama penyinaran, kelembapan udara, kecepatan angin, suhu udara, tingkat penguapan dan tingkat kejenuhan air bahan baku garam. Berdasarkan nilai IKG yang diberikan dalam penelitian ini, tingkat kesesuaian lokasi produksi garam bisa ditentukan dari kategori kurang sesuai sampai dengan sangat sesuai. Penelitian ini adalah penelitian pertama yang melaporkan metode dalam menentukan tingkat kesesuaian suatu area untuk dijadikan 
lokasi produksi garam. Curah hujan dan lama penyinaran harian didapatkan dari Badan Meteorologi, Klimatologi, dan Geofisika (BMKG).

\section{METODE PENELITIAN}

\section{Lokasi Penelitian}

Penelitian analisis kesesuaian lokasi produksi garam di Jawa Timur ini dilaksanakan di Desa Leranwetan, Kecamatan Palang, Kabupaten Tuban dan Desa Kalibuntu Blok Ladangan, Kecamatan Kraksaan, Kabupaten Probolinggo. Waktu pelaksanaan kegiatan penelitian ini dilakukan dari bulan Maret sampai November 2018.

Pemilihan kedua lokasi tersebut didasarkan pada potensi tambak garam dengan mempertimbangkan kontinuitas usaha produksi garam dan target integrasi lahan produksi garam. Selain itu, kedua lokasi ini memiliki sumber bahan baku air laut yang berbeda (air laut dan air sungai payau).

\section{Pendekatan Penelitian}

Metode yang digunakan dalam kegiatan ini adalah metode campuran antara kualitatif dan kuantitatif (Mixed Methods) dengan pendekatan deskriptif yang dilakukan untuk menguji hipotesis penelitian dan menggambarkan hal yang ada tentang suatu variable. Sementara itu, penentuan lokasi sampling dengan menggunakan purposive sampling. Variabel dalam penelitian ini meliputi parameter dalam Indeks Kesesuaian Garam (IKG) pada Tabel 1 yang meliputi: curah hujan $(\mathrm{mm})$, jens tanah, permeabilitas tanah (k), lama penyinaran (jam/hari), kelembapan udara $(\%)$, kecepatan angin $(\mathrm{m} / \mathrm{s})$, suhu udara $\left({ }^{0} \mathrm{C}\right)$, laju penguapan $(\mathrm{mm} / \mathrm{hari})$, dan tingkat kejenuhan air bahan baku $\left({ }^{\circ} \mathrm{Be}\right)$.

\section{Pengukuran parameter IKG}

Sampel tanah dibawa dalam plastik polietilen ke laboratorium untuk dianalisis. Jenis tanah dianalisis dengan metode Segitiga Tekstur Tanah. Permeabilitas tanah dianalisis menggunakan metode Constant Head Permeameter dan Variable/Falling Head Permeameter. Suhu udara diukur dengan menggunakan Termometer Digital (HTC-2).
Kecepatan angin diukur dengan menggunakan Anemometer Digital (GM8902, Benetech). Laju penguapan diestimasi dari penurunan ketinggian air (cm/hari). Kelembapan diukur dengan menggunakan Higrometer Digital (HTC-2). Tingkat kejenuhan air (Skala Baumé) diukur dengan Boumehydrometer (Alla france, 0-30).

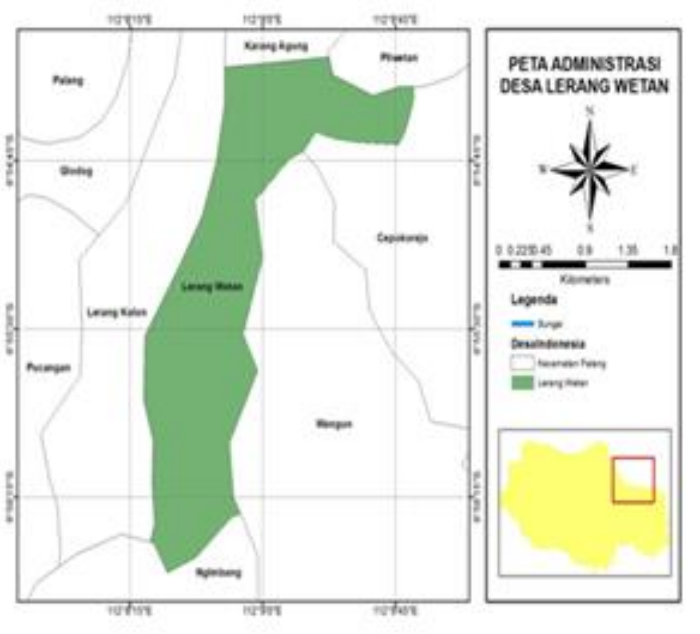

Gambar 1. Peta Desa Leranwetan, Tuban

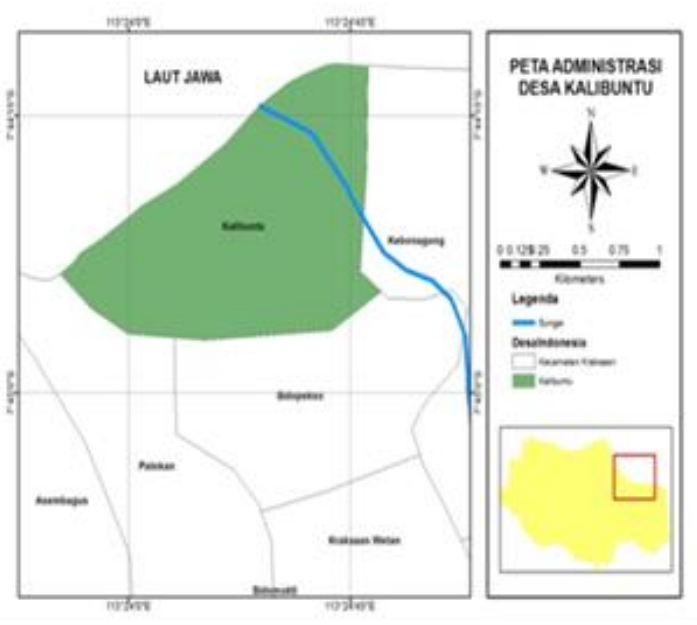

Gambar 2. Peta Desa Kalibuntu, Probolinggo

\section{Analisis Data}

Analisis data dilakukan dengan menggunakan analisis kuantitatif untuk memudahkan pengambilan kesimpulan terkait kesesuaian lokasi produksi garam. Perhitungan didasarkan pada tingkat kesesuaian sembilan indikator kesesuaian lokasi produksi garam. Tingkat kesesuaian lokasi dihitung dengan menggunakan rumus 
penilaian kelas kesesuaian fisik tambak garam sebagaimana berikut ini:

$$
I K G=(\Sigma \mathrm{Ni} / \mathrm{Nmaks}) \times 100 \%
$$

Keterangan:

IKG : Indeks Kesesuaian Lokasi Produksi

$\mathrm{Ni} \quad$ : Nilai Parameter ke-i (bobot $\times$ skor)

Nmaks : Nilai Maksimum dari suatu kategori

Kriteria kesesuaian berdasarkan skor IKG adalah sebagaimana berikut ini:
$>85 \%$
: Sangat sesuai (S1)
$80-84 \%$
: Cukup Sesuai (S2)
$75-79 \%$
: Sesuai bersyarat (S3)
$<75 \%$
: Tidak sesuai $(\mathrm{N})$

\section{HASIL DAN PEMBAHASAN}

Penelitian ini menganalisis tingkat kesesuaian lokasi tambak garam di Kabupaten Tuban (Desa Leranwetan) dan Kabupaten Probolinggo (Desa Kalibuntu) untuk dijadikan lahan produksi garam dengan menggunakan Indeks Kesesuaian Garam (IKG). IKG menggunakan standar dari sembilan parameter untuk menganalisis lokasi produksi garam (Tabel 1). Hasil pengukuran sembilan parameter ini diuraikan pada Tabel 2 untuk Kabupaten Tuban dan Tabel 3 untuk Kabupaten Probolinggo.

\section{Curah Hujan}

Analisis kesesuaian lokasi produksi garam berdasarkan kondisi curah hujan dilakukan dengan menganalisis nilai rata-rata curah hujan tahunan. Rata-rata curah hujan di Desa Leranwetan Kabupaten Tuban adalah sebesar 5,6 $\mathrm{mm}$ sedangkan di Kabupaten Probolinggo adalah sebesar $6,8 \mathrm{~mm}$. Hasil ini menunjukan bahwa curah hujan di Kabupaten Tuban lebih rendah dibandingkan dengan Kabupaten Probolinggo. Curah hujan sendiri merupakan salah satu penentu keberhasilan target produksi garam [9]. Rata-rata intensitas curah hujan dan pola hujan dalam setahun merupakan indikator yang terkait erat dengan lama musim kemarau. Lama musim kemarau ini akan mempengaruhi tingkat penguapan air di lokasi produksi garam. Tingkat curah hujan yang tinggi akan berdampak negatif pada produksi garam [10].
Hasil penelitian ini menunjukkan bahwa nilai IKG untuk curah hujan di kedua lokasi tersebut memiliki nilai indeks 20, sehingga masuk ke dalam katagori kelas S1. Hasil ini mengindikasikan kalau lokasi-lokasi tersebut, berdasarkan pada tingkat rata-rata curah hujan, sudah sangat sesuai sebagai lokasi produksi garam.

\section{Permeabilitas Tanah}

Hasil pengukuran permeabilitas tanah di masing-masing lokasi produksi garam menunjukkan bahwa nilai permeabilitas tanah tambak garam di Kabupaten Tuban adalah sebesar 1 x $10^{-3}(\mathrm{k})$, sedangkan nilai permeabilitas tanah tambak garam di Kabupaten Probolinggo adalah sebesar 1 x 10 ${ }^{2}$ (k). Permeabilitas tanah di lokasi tambak garam di Kabupaten Tuban lebih rendah daripada di tambak garam di Kabupaten Probolinggo.

Permeabilitas tanah rendah dan tidak mudah retak adalah salah satu kriteria dalam persyaratan lokasi tambak garam [11]. Parameter ini juga merupakan parameter penting yang menentukan tingkat porositas tanah. Tingkat porositas juga merupakan faktor penting yang mempengaruhi keberhasilan produksi garam [10]. Nilai IKG untuk permeabilitas tanah di Kabupaten Tuban adalah 15 dan Kabupaten Probolinggo adalah 10. Hasil ini mengindikasikan bahwa lokasi tambak garam di Kabupaten Tuban berdasarkan tingkat permeabilitas tanah termasuk dalam kategori cukup sesuai (S2), sedangkan tambak garam di Kabupaten Probolinggo termasuk kategori sesuai bersyarat (S3).

\section{Jenis Tanah}

Analisis jenis tanah pada lokasi penelitian ini menunjukan bahwa jenis tanah tambak garam di Kabupaten Tuban adalah tanah berlempung, sedangkan jenis tanah di Kabupaten Probolinggo adalah tanah lempung berpasir. Sistem pori tanah sangat dipengaruhi salah satunya oleh tipe tanah [11] [12] [13]. Hasil analisis IKG untuk jenis tanah menunjukan bahwa nilai IKG jenis tanah untuk Kabupaten Tuban adalah 20 (sangat sesuai), sementara lokasi tambak garam di 
Kabupaten Probolinggo adalah 15 (cukup sesuai).

Tanah-tanah yang didominasi fraksi pasir akan mempunyai pori makro (porous), tanah dengan dominasi debu akan banyak mempunyai pori meso (agak porous), sementara tanah dengan fraksi liat akan mempunyai banyak pori mikro (kecil) atau tidak porous [14]. Pengembangan lahan tambak garam harus didasarkan pada potensi teknis yang dimiliki wilayah pengembangan, salah satu potensi teknis tersebut adalah jenis tanah yang tidak porous untuk menjamin ketersedian air tua dan pengendapan sempurna [15].

\section{Lama Penyinaran}

Hasil analisis terkait lama penyinaran pada tambak garam di Kabupaten Tuban menunjukan lama penyinaran matahari di lokasi ini adalah 8,8 jam/hari. Lama penyinaran pada lokasi tambak garam di Kabupaten Probolinggo adalah 7,5 jam/hari. Lama penyinaran matahari merupakan faktor dalam produksi garam yang juga mempengaruhi laju evaporasi air. Evaporasi air akan dapat tercapai dengan baik jika didukung oleh radiasi surya serta bantuan rekayasa iklim mikro pada areal pegaraman [16].

Penilaian parameter terkait waktu penyinaran matahari menunjukan kalau tambak garam di Kabupaten Tuban menunjukkan nilai IKG untuk lama penyinaran 20, sedangkan pada lokasi penelitian di Kabupaten Probolinggo menunjukkan nilai IKG lama penyinaran 15. Lama penyinaran di lokasi produksi garam sangat berpengaruh bagi laju evaporasi, dimana semakin tinggi laju evaporasi dapat semakin meningkatan tingkat kejenuhan air bahan baku pembuatan garam [8].

\section{Kelembaban Udara}

Hasil pengukuran kelembapan udara pada tambak garam di Kabupaten Tuban menunjukkan nilai kadar kelembapan udara sebesar 51\% (S2) dan di Kabupaten Probolinggo menpunyai kadar kelembapan udara sebesar 55\% (S2). Kelembapan udara berkaitan erat dengan proses evaporasi pada produksi garam. Jika kelembapan tinggi, laju evaporasi menjadi rendah karena kejenuhan udara akan lebih cepat tercapai. Kelembapan udara mempengaruhi kecepatan penguapan air, dimana makin besar penguapan maka makin besar jumlah kristal garam yang mengendap [17]. Sesuai penilaian parameter kelembapan udara, maka pada lokasi penelitian di Desa Leranwetan Kabupaten Tuban mempunyai nilai IKG kelembapan udara sebesar 15, sedangkan pada lokasi penelitian di Kabupaten Probolinggo memiliki nilai IKG kelembapan udara 15.

\section{Kecepatan Angin}

Berdasarkan pengamatan tingkat kecepatan angin, Desa Leranwetan, Kabupaten Tuban memiliki tingkat kecepatan angin sebesar 4,6 m/s (S2), sementara Desa Kalibuntu, Kabupaten Probolinggo sebesar $6,3 \mathrm{~m} / \mathrm{s}(\mathrm{S} 3)$. Kecepatan angin yang tinggi akan membantu dalam proses mempercepat produksi garam.

Kecepatan angin sangat berpengaruh dalam penentuan lokasi tambak garam karena akan mempengaruhi kecepatan penguapan air, dimana makin besar evaporasi (penguapan) maka makin besar jumlah kristal garam yang mengendap [8]. Pada penilaian parameter kecepatan angin, maka pada lokasi penelitian di Desa Leranwetan, Kabupaten Tuban memiliki nilai IKG untuk kecepatan angin 15, sementara lokasi penelitian di Desa Kalibuntu, Kabupaten Probolinggo memiliki nilai IKG kecepatan angin 20.

\section{Suhu Udara}

Hasil pengukuran suhu udara menunjukkan lokasi produksi garam di Desa Leranwetan, Kabupaten Tuban memiliki suhu udara berkisar $35^{\circ} \mathrm{C}$ (S1), dan di Desa Kalibuntu, Kabupaten Probolinggo berkisar $35^{\circ} \quad \mathrm{C}$ (S1). Proses pembuatan garam bergantung pada laju evaporasi air garam yang salah satunya dipengaruhi oleh aktifitas panas yang berfungsi untuk memanaskan molekul-molekul air yang dibutuhkan untuk penguapan [18].

Suhu udara mempengaruhi kecepatan penguapan air, dimana makin besar penguapan maka makin besar jumlah kristal 
garam yang mengendap [17]. Lokasi tambak garam di Desa Leranwetan, Kabupaten Tuban memiliki nilai IKG untuk suhu udara 20, sama dengan nilai untuk lokasi tambak garam di Desa Kalibuntu, Kabupaten Probolinggo.

\section{Penguapan}

Penguapan merupakan faktor utama dalam produksi garam yang dipengaruhi oleh angin dan matahari. Proses pembuatan garam pada dasarnya adalah proses pengoptimalan proses penguapan sehingga dapat menghasilkan Kristal garam. Hasil pengukuran tingkat penguapan air di lokasi produksi garam di Kabupaten Tuban menunjukkan tingkat penguapan di lokasi ini adalah sebesar 2,5 mm/hari (Kategori S1), sedangkan di Kabupaten Probolinggo adalah sebesar $2 \mathrm{~mm} /$ hari (Kategori S2).

Faktor yang paling menentukan kecepatan penguapan air dalam proses pembuatan garam adalah kecepatan angin dan radiasi sinar matahari. Kecepatan angin berpengaruh karena angin membawa uap air dari permukaan air sehingga proses penguapan tetap dapat berlangsung. Radiasi sinar matahari berpengaruh karena merupakan sumber energi untuk proses penguapan yang terjadi [19]. Analisis tingkat penguapan menunjukkan bahwa nilai IKG untuk penguapan air pada lokasi produksi garam di Kabupaten Tuban dan di Kabupaten Probolinggo adalah sama-sama 20.

\section{Kejenuhan Air Bahan Baku}

Proses pembentukan kristal garam dipengaruhi banyak faktor termasuk tingkat kejenuhan air bahan baku garam. Tingkat kejenuhan ini akan menentukan berapa lama waktu yang dibutuhkan untuk memproduksi garam. Tingkat kejenuhan air bahan baku garam dalam penelitian ini dianalsis berdasarkan derajat Skala Baumé $\left({ }^{\circ} \mathrm{Be}\right)$.

Hasil pengukuran tingkat kejenuhan air di lokasi produksi garam di Kabupaten Tuban adalah rata-rata $2{ }^{\circ} \mathrm{Be}$ (Kategori S1), sementara di Kabupaten Probolinggo adalah rata-rata $3{ }^{\circ} \mathrm{Be}$ (Kategori S1). Waktu produksi garam dari air bahan baku garam hingga menghasilkan kristal garam dipengaruhi oleh parameter-parameter meteorologi, seperti curah hujan, evaporasi, perawanan, dan angin permukaan dan tingkat kejenuhan air bahan baku itu sendiri [20]. IKG untuk tingkat kejenuhan air bahan baku garam baik pada lokasi tambak garam di Kabupaten Tuban maupun Kabupaten Probolinggo adalah 20.

\section{Nilai IKG Keseluruhan}

Setelah mendapatkan nilai IKG untuk masing-masing parameter seperti dijelaskan diatas, langkah berikutnya dalam analisis kesesuaian lokasi garam adalah menghitung nilai IKG total dengan menggunakan rumus (1). Nilai IKG total inilah yang akan dijadikan sebagai rujukan untuk menentukan tingkat kesesuaian lokasi untuk produksi garam.

Hasil penelitian ini menunjukkan bahwa nilai IKG total lokasi produksi garam di Kabupaten Tuban (Desa Leranwetan) adalah sebesar $86,84 \%$ yang mengindikasikan kalau lokasi ini sudah sangat sesuai untuk produksi garam. Untuk nilai IKG lokasi produksi garam di Kabupaten Probolinggo (Desa Kalibuntu) adalah sebesar $81,57 \%$ yang mengindikasikan lokasi ini cukup sesuai sebagai lokasi produksi garam.

Perbedaan tingkat kesesuaian antara lokasi tambak garam di Kabupaten Tuban dan Kabupaten Probolinggo dikarenakan jenis tanah pada lokasi tambak garam di Kabupaten Probolinggo adalah Sandy Clay. Tanah jenis ini cenderung lebih poros. Oleh karena itu dibutuhkan teknologi sebagai upaya untuk mengatasi tingkat porositas tanah. Salah satu alternatif teknologi yang bisa digunakan adalah penggunaan geomembran untuk melapisi dasar tambak garam. Penggunaan geomembran bukan hanya akan mengatasi porositas lahan tapi juga dapat menghasilkan garam yang lebih bersih [5] [6].

Tambak garam di Kabupaten Tuban walaupun tidak berada langsung di tepi laut, tetap memiliki sumber air bahan baku dengan tingkat kejenuhan yang memadai $\left( \pm 2{ }^{\circ} \mathrm{B}\right)$. Hal ini yang menyebabkan walaupun tidak berada langsung di tepi laut, kawasan ini bisa digunakan sebagai lokasi tambak garam. Dengan menganalisis keseluruhan parameter dalam IKG, maka dapat diketahui bahwa lokasi tambak garam di Kabupaten Tuban sudah sangat sesuai untuk proses produksi 
garam. Hanya saja, hal ini bukan berarti penggunaan teknologi seperti geomembran tidak akan membawa keuntungan. Pengaplikasian geomembran tetap dapat memberi keuntungan tambahan terkait dengan kualitas garam yang dihasilkan.

Table 1. Nilai Parameter Indeks Kesesuaian Garam (IKG)

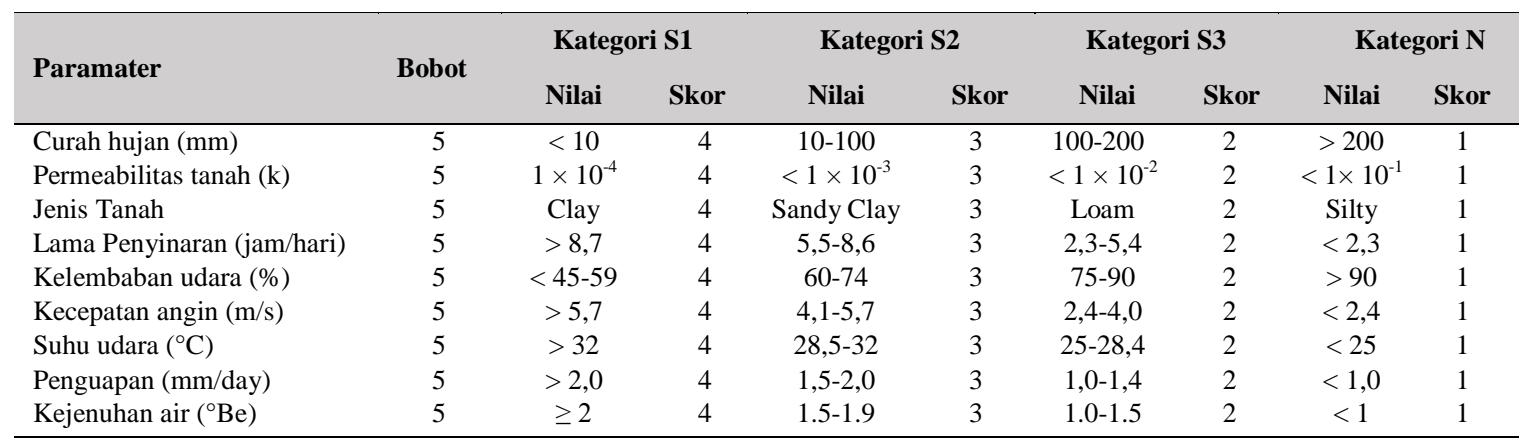

Keterangan: S1: Sangat Sesuai; S2: Cukup Sesuai; S3: Sesuai Bersyarat; N: Tidak Sesuai

Tabel 2. Parameter Kesesuaian Lokasi Produksi Garam di Desa Leran Wetan, Kabupaten Tuban

\begin{tabular}{|c|c|c|c|c|c|c|}
\hline No & Paramater & Hasil Pengukuran & Kategori & Bobot & Skor & $\mathbf{N i}=\mathbf{B} \times \mathrm{S}$ \\
\hline 1 & Curah hujan (mm) & 5,6 & S1 & 5 & 4 & 20 \\
\hline 2 & Permeabilitas tanah $(\mathrm{k})$ & $1 \times 10^{-3}$ & $\mathrm{~S} 2$ & 5 & 3 & 15 \\
\hline 4 & Lama penyinaran (jam) & 8,8 & $\mathrm{~S} 2$ & 5 & 3 & 15 \\
\hline 5 & Kelembapan udara (\%) & 51 & $\mathrm{~S} 2$ & 5 & 3 & 15 \\
\hline 6 & Kecepatan angin $(\mathrm{m} / \mathrm{s})$ & 4,6 & $\mathrm{~S} 2$ & 5 & 3 & 15 \\
\hline 9 & Kejenuhan air bahan baku $\left({ }^{\circ} \mathrm{Be}\right)$ & 2 & $\mathrm{~S} 1$ & 5 & 4 & 20 \\
\hline
\end{tabular}

Tabel 3. Parameter Kesesuaian Lokasi Produksi Garam di Desa Kalibuntu, Kabupaten Probolinggo

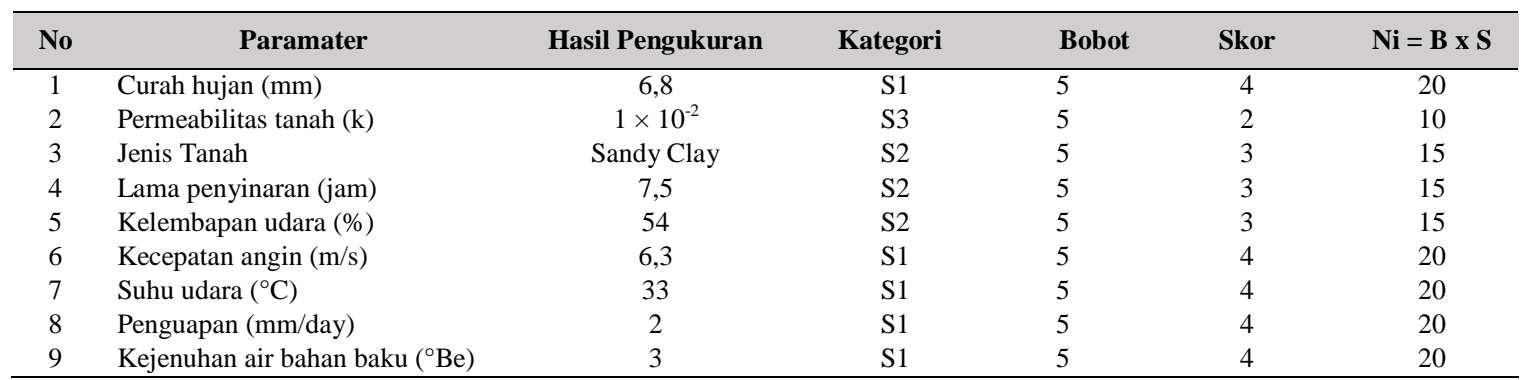

\section{KESIMPULAN}

Penelitian ini mengembangkan Indeks Kesesuaian Garam (IKG) sebagai metode analisis untuk mengetahui tingkat kesesuaian suatu lokasi menjadi lahan produksi garam. Berdasarkan analisis IKG didapatkan kalau lokasi produksi garam di Kabupaten Tuban (Desa Leranwetan) termasuk ke dalam kategori Sangat Sesuai untuk dijadikan lokasi produksi garam rakyat (nilai IKG sebesar $86,84 \%$ ). Lokasi produksi garam di Kabupaten Probolinggo (Desa Kalibuntu) masuk dalam kategori Cukup Sesuai dijadikan 
lokasi produksi garam (nilai IKG 81,57\%). Hal yang harus menjadi perhatian utama terkait kesesuaian lokasi produksi garam di Kabupaten Probolinggo adalah jenis tanah yang secara umum Sandy Clay yang membutuhkan teknologi seperti penggunaan geomembran untuk dapat mengoptimalkan produksi garam. Lokasi produksi garam di Kabupaten Tuban walaupun tidak berada di pantai sesuai dijadikan lokasi tambak garam karena memiliki sumber air bahan baku pembuatan garam dengan tingkat kejenuhan rata-rata $\pm 2{ }^{\circ} \mathrm{Be}$.

\section{UCAPAN TERIMA KASIH}

Peneliti menyampaikan terima kasih kepada pihak-pihak yang mendukung dan memberikan masukan dalam penelitian ini, diantara lain adalah: Dr.Sc. Asep Awaludin Prihanto dan Dr. Ir. Guntur, MS dari FPIK UB, Zulkisam Pramudia, Lisa Nurhidayah, Yogita Ayu Dwi Susanti, Gatot Ardian dari PSPK UB, Badan Penelitian dan Pengembangan Daerah Provinsi Jawa Timur, Dinas Perikanan dan Peternakan Kabupaten Tuban, Dinas Perikanan dan Kelautan Kabupaten Probolinggo, PT. Kencana Tiara Gemilang, dan Badan Penelitian dan Pengabdian Kepada Masyarakat FPIK UB.

\section{DAFTAR PUSTAKA}

[1] Kirabira J. B, Kasedde H, Lwanyaga D, "Optimization Of Process Parameters In The Batch Crystallization Of Sodium Chloride From Brine By The Taguchi Method," Int. J. Sci. Technol. Res., vol. 6 hal. 160-165, Agust 2017.

[2] Stan-Lotter H, and Fendrihan S, "Deep Biosphere of Salt Deposits," Encyclopedia Geobiology., hal. 927, Mei 2011.

[3] Rusiyanto, Soesilowati E, Jumaeri, "Penguatan Industri Garam Nasional Melalui Perbaikan Teknologi Budidaya dan Difersifikasi Produk," $J$. Sains dan Tekn., vol 11, no 2, Des
2013.

[4] Salim Z, Munadi E, B, "Info Komoditi Garam," Badan Pengkajian dan Pengembangan Perdagangan, Kementrian Perdagangan Republik Indonesia: Jakarta, 2016.

[5] G. Guntur, A. A. Jaziri, A. A. Prihanto, D. M. Arisandi, and A. Kurniawan, "Development of salt production technology using prism greenhouse method," IOP Conference Series: Earth and Environmental Science, Jul 2018.

[6] A. A. Jaziri, Guntur, W. Setiawan, A. A. Prihanto, and A. Kurniawan, "Preliminary design of a low-cost greenhouse for salt production in Indonesia," IOP Conference Series: Earth and Environmental Science, Apr 2018.

[7] I. Ihsannudin, S. Pinujib, S. Subejo, and B. Sumada Bangko, "Strategi Pemberdayaan Ekonomi Petani Garam Melalui Pendayagunaan Aset Tanah Pegaraman," J. Econ. Dev. Anal., vol. 5, no. 4, Nov 2016

[8] Tambunan B R, Hariyadi, Santoso A, "Evaluasi Kesesuaian Tambak Garam Ditinjau Dari Aspek Fisik Di Kecamatan Juwana Kabupaten Pati," J. Mar. Res., vol. 1, no. 2, hal 181-187, Feb 2012.

[9] Zuhud A, “Analisis Pengaruh Laju Evaporasi dan Curah Hujan Terhadap Produksi Garam di Lahan Penggaraman PT Garam (Persero) Sumenep," Skripsi. Institut Teknologi Bandung: Bandung, 2014.

[10] D. Purbani, "Proses Pembentukan Kristalisasi Garam," Pus. Ris. Wil. Laut dan Sumberd. Nonhayati, Departemen Kelautan dan Perikanan Indonesia: Jakarta, 2006. 
[11] M. Kutílek, L. Jendele, and K. P. Panayiotopoulos, "The influence of uniaxial compression upon pore size distribution in bi-modal soils," Soil Tillage Res., vol. 86 no.1, hal 27-37, Mar 2006.

[12] M. Wairiu and R. Lal, "Tillage and land use effects on soil microporosity in Ohio, USA and Kolombangara, Solomon Islands," Soil Tillage Res., vol. 88 no.1. hal 80-84, Mar 2006.

[13] H. C. Chun, D. Giménez, and S. W. Yoon, "Morphology, lacunarity and entropy of intra-aggregate pores: Aggregate size and soil management effects," Geoderma., vol.146 no.1, hal 83-93, Jul 2008.

[14] K. A. "Hanafiah, Dasar-Dasar Ilmu Tanah," Raja Grafindo Persada: Jakarta, 2007.

[15] A. Mustafa, Hasnawi, A. Athirah, A. Sommeng, dan S. A. Ali, "Karakteristik, Kesesuaian, dan Penlolaan Lahan untuk Budidaya di Tambak Kabupaten Pohuwato, Provinsi Gorontalo", J. Riset Akuakultur., vol. 9, no. 1, hal 135-149, Mar 2014.

[16] A. Kumala, "Analisis Pengaruh Curah Hujan terhadap Produktivitas Garam (Studi Kasus: Pegaraman I Sumenep, PT.Garam (Persero))," Skripsi. Institut Pertanian Bogor: Bogor, 2012.

[17] K. Kartikasari, "Potensi Pemanfaatan Informasi Prakiraan Iklim Untuk Mendukung Sistem Usaha Tambak Udang dan Garam Di Kabupaten Indramayu," Skripsi. Institut Pertanian Bogor: Bogor, 2007.
[18] PT. Garam, "Teknologi Pembuatan dan Kendala Produksi Garam di Indonesia, ". Kementrian Kelautan dan Perikanan: Jakarta, 2000.

[19] I. Santosa, "Pembuatan Garam Menggunakan Kolam Kedap Air Berukuran Sama," Spektrum Ind., vol. 12, no. 1, hal. 1-112, Apr 2014.

[20] S. Sandy H. S, Gisma A. F, Plato M, "Pengaruh Aspek Meterologi Terhadap Produksi Garam Air Payau di Desa Losarang, Kabupaten Indramayu," SEMIRATA MIPA Unsrat Manado., Agust, 2017. 